\title{
Mir-Said Sultan-Galiev and the Idea of Muslim Marxism: Empire, Third World(s) and Praxis
}

\author{
Vanja Hamzić \\ SOAS, University of London
}

\begin{abstract}
This paper revisits the idea of Muslim Marxism, as espoused through the life and work of the Tatar Muslim and Bolshevik intellectual and revolutionary MirSaid Sultan-Galiev (1892-1940). I argue that Sultan-Galiev's oeuvre-a unique synthesis of Marxist, Muslim modernist, anti-colonial and Third World praxisrepresents a path-breaking take on Muslim selfhood and practices of belonging.
\end{abstract}

Keywords: Mir-Said Sultan-Galiev; Muslim Marxism; jadìdism; satr; praxis; Colonial International; Empire; Tatarstan; Bolshevism; Islamic modernism

Marxist and Muslim lifeworlds nowadays do not converge a lot. They are generally thought so much apart, both in theory and practice, that any mention of 'Muslim Marxism' appears hopelessly oxymoronic. Marx's denunciation of religion as 'the opium of the people'1 and countless accounts of religious persecution under the communist rule are often invoked as a grim reminder of the supposed incompatibility of Marxist and Muslim ideas. Yet, historically, such incompatibility is tenuous. Not only did many Muslim thinkers tend towards Marxism (a tendency so neatly captured by the French adjective marxisant) ${ }^{2}$ and vice versa, in ways more than one; 3 there also emerged, especially in the Worlds designated as Third, ${ }^{4}$ idiosyncratic forms of individual and collective praxis whose transformative potential was owed precisely to the idea that rudimentary Marxist views on social and economic justice can and must be reconciled with those of Muslim political and social consciousness.

Nowhere can this bold idea-the idea of Muslim Marxism-be better traced than to the eventful life and legacy of the controversial Tatar Muslim and Bolshevik political and social reformer Mir-Said Sultan-Galiev (in Tatar: Mirsäyet Soltanğäliev; 18921940). Caught between the demise of one long-standing empire and a rapid rise of 
another, that is, between the unmaking of czarist Russia and the making of the Soviet Union, Sultan-Galiev's story is that of a personal and ideological struggle in an inauspicious time; a story of an avant-garde take on Muslim subjectivity, tradition and revolutionary potential, albeit with a tragic ending.

Sultan-Galiev's good repute amongst the Muslims and communists alike of the revolutionary and post-revolutionary Russia of the early twentieth century, earned in an unusually rapid fashion, made him a chief authority on the so-called 'Eastern Question', which in the Soviet context mainly related to its vast eastern territories, populated, amongst others, by millions of Muslims, largely of Turkic origins. It is this anxiety of the emerging Soviet state about its Eurasian Muslim populace-famously exemplified in Lenin's observation that one has to be a thousand times more careful and accommodating than usual when dealing with these 'national minorities'5 - that provided Sultan-Galiev and other like-minded Muslim activists with an opportunity to negotiate a rather unique, even if short-lived, position for Soviet Muslims, of not only relative freedom to worship and association in an age of militant atheism but also of increasing participation in the state's political and military affairs. Sultan-Galiev's ambitions were, however, much greater, and had he managed to retain the trust of Stalin and his inner circle towards the close of the interbellum period, he may have wrestled an even greater autonomy for Soviet Muslims. Indeed, he may even (as he would later be accused of planning) have spearheaded a revolutionary insurgency of his own, which, in all likelihood, would have been Muslim and Third World socialist in nature.

The intent of this article is to provide a preliminary critical reassessment of the rise and fall of Muslim Marxism of Sultan-Galiev's type. Sultan-Galiev's own works, spanning a variety of genres from poetry and prose in Muslim social and educational magazines to relentlessly Bolshevik political writing in state-sanctioned journals such as Zhizn' natsional'nostei (The Life of Nationalities), offer a rich source of analysis in their own right, and are particularly useful when compared with archival data on his party work, trials and prison notes, including an autobiographical letter. ${ }^{6}$ Most of these sources are still available in Russian and Tatar only. This is, however, not to say that some of Sultan-Galiev's works have not been of interest to a much wider scholarly and activist community; ${ }^{7}$ my argument is, rather, that specifically Muslim dimensions of his social and political mission were more often than not sidelined in contemporary accounts of his life and work, or were given unduly literalist explanations. ${ }^{8}$

I would like to propose that such readings of Sultan-Galiev's thought and actions fail to take into account his extraordinarily difficult political position, as a chief mediator between, on the one hand, an increasingly autocratic Soviet socialist elite, 
bearing all hallmarks of Said's Orientalism and Great-Russian chauvinism, and the reform-minded Muslim Eurasians, on the other. This is particularly true with regards to his interpretation of Muslim subjectivity, which uses but ultimately transgresses the early twentieth-century concepts of ethnic, national and religious belonging in order to re-imagine and give primacy to Muslim political-and, indeed, revolutionary-umma (community). It is equally evident in his formative years, which involved Muslim religious schooling of the so-called jadīist type, thus inextricably linking his educational experience with the work of an earlier Muslim reformer, Ismail Gasprinskil (in Turkish: İsmail Gaspıralı, 1851-1914), a Crimean Tatar deeply invested in a Muslim modernist educational, linguistic and cultural project that had transformed beyond recognition the educational landscape of the late tsarist Russia. ${ }^{9}$ I argue that the ușūl aljadīd, or 'new method', that Gasprinskil had introduced to Muslim schools and popularised, as a form of critical thinking, amongst Muslim intelligentsia in the turbulent fin-de-siècle period immediately preceding the fall of the Russian Empire, had given Mir-Said Sultan-Galiev an invaluable model for his future work. A key element of this model, befitting the trying times and circumstances of both Gasprinskiri's and Sultan-Galiev's lifeworlds, is that of satr, or 'concealment' for the greater good, which the two reformers have exercised and perfected in their own idiosyncratic ways, thus escaping censorship and other, ostensibly more serious, forms of repression. In Gasprinskiı̌'s case, it enabled the gradual introduction of over 5,000 ușūl al-jadīd schools in Russia by 1916 and the creation of an important intellectual movement that in many ways had assisted the survival of Muslim social and political life in the times to come. In Sultan-Galiev's case, it evolved into a full-fledged revolutionary methodology of rare sophistication; so rare, in fact, that it continues to befuddle the connoisseurs of his work until this very day. I will propose here, albeit with some caution, that the strategic deployment of satr by Gasprinskil and Sultan-Galiev, which only a careful deduction can reveal, as it is never explicitly stated, is reminiscent of the satr that used to be a staple of Ottoman social relations, as averred, for example, around the year 1601, by the Ottoman jurist 'Ālī al-Qārî̀' al-Harawī. ${ }^{10}$ In a sense, then, Gasprinskiı̌'s and Sultan-Galiev's uses of concealment for the 'greater good' represent a revival of an important principle from a milieu not entirely strange to either of the two reformers.

What follows, then, is an attempt to re-contextualise Sultan-Galiev's oeuvre with a particular focus on its Muslim-specific elements. I will first introduce his take on Muslim subjectivity and praxis, which I understand to be an amalgamation of his personal experience of class-based injustice, his jadidist views and his deep-felt revolutionary cause directed at liberating Muslims from colonial oppression, firstly in respect to his own (Tatar and Bashkir) populace struggling under Russian imperialism, and then Muslims in the Third World(s) writ large, with Euro-American capitalist 
imperialism and native metropolitan bourgeoisie identified as their arch-enemies. I will then address Sultan-Galiev's political interventions aimed specifically at building a Muslim socialist movement. After initial success, this would become a vexed matter, involving, shortly before its downfall in the hands of the Stalinist state, a series of clandestine interactions that ultimately cost Sultan-Galiev his life as well as the lives of much of his family and his real or imagined political inner circle. Finally, I will briefly reflect on some of the afterlives of Muslim Marxism in places geographically far away but close in terms of religious and political belonging to Sultan-Galiev's homeland, and their enduring, if uncanny, relevance for the contemporary reformulations of Muslim religious, political and social selfhood.

\section{Sultan-Galiev's early life and directions}

Mir-Said Sultan-Galiev was born in 1892 in the Bashkir village of Elembet'evo in the Ufa governorate, which was then part of the Russian Empire. His father, a respected schoolteacher, followed Gasprinskiü's 'new method'11 in teaching his Muslim pupils, including the young Mir-Said. Apart from what was called 'Islamic history and methods of thought', the curriculum included a variety of social and natural sciences as well as languages other than Russian, such as Tatar and Arabic. ${ }^{12}$ Mir-Said's particular passion was Russian literature, which he was able to read in its original language from an early age, as well as Muslim folk stories and customs. The jadidist schooling taught him critical thinking, however, and some of his earliest contributions to the Muslim press were directed against customary practices that he thought repugnant to modern Muslim culture, such as the hudūd punishments for the offence of zina. ${ }^{13}$ His further education, directed towards his becoming a teacher himself, as well as his literary and journalist work, quickly gained support from Tatar jadidist intelligentsia. Yet, his own class experience gave him an opportunity to reflect upon an element that was still clearly missing from Muslim Tatar life-that of social equality and economic justice.

Sultan-Galiev was born into a 'mixed' family of a father who proudly called himself a Mishar (Mişär), a member of a Tatar peasant community, ${ }^{14}$ and a mother who came from a Tatar noble family. In an autobiographical letter, Sultan-Galiev reflected upon the continuous bullying he was subjected to by his mother's cousins at her father's estate as formative of his early class-consciousness. 'Thus', he wrote in 1923, 'the farmstead of my grandfather was for me the first and most realistic revolutionary school, cultivating in me a feeling of class hatred'. ${ }^{15}$ It is, one can assume, this feeling of his-and the lack thereof in his Tatar intellectual circles-that pushed Sultan-Galiev to Marxist literature, which he read very sparsely. Surprisingly, perhaps, this literature did not impress him very much. What he was after was a social and political movement able 
to tackle class difference in everyday life and, in his jadidist mind, one that could simultaneously respond to colonial injustices felt by Muslims everywhere. In his own words, written in 1917, Sultan-Galiev attested that he had discovered such a movement in the form of the Bolsheviks, because 'they had done more for the Muslims than anyone else':

Only they are striving to transfer the nationalities' fates into their own hands. Only they revealed who started the world war. What doesn't lead me to them? They also declared war on English imperialism, which oppresses India, Egypt, Afghanistan, Persia and Arabia. They are also the ones who raised arms against French imperialism, which enslaves Morocco, Algeria and other Arab states of Africa. How could I not go to them? You see, they uttered the words that have never been uttered before in the history of the Russian state. Appealing to all Muslims of Russia and the East, they announced that Istanbul must be in Muslims' hands. ${ }^{16}$

This confession reveals some of the elementary tenets of Sultan-Galiev's revolutionary project. His first concern, even when it was not explicitly stated, seemed always to be for Muslims, whose subjectivity he loosely construed as one marked by continuous class and colonial oppression. They were, for him, the most perfect example of Third World proletariat, whose history and social cohesion had made them uniquely placed to ignite and lead world revolution. Although he frequently used concepts such as 'nationality' and showed special interest in the liberation of Turkic nations from tsarist colonialism and then from post-revolutionary Russian hegemony, in all likelihood he saw panTurkism, of which he was often accused, as but one of the potential avenues towards global Muslim socialist uprising.

\section{Race, class and the Colonial International}

Another struggle, directly associated with Sultan-Galiev's project of world revolution, which was often hinted at but, yet again, somewhat obliquely formulated in his writing, was the struggle for racial equality. He wrote of colonialists 'domestic' and 'foreign', as it were, as white racists, who exploited non-white populations of the East, in which he occasionally included the native populations of the Americas, simply on the basis of perceived racial difference. ${ }^{17}$ It is plain that he had excluded Turkic and Caucasian Muslims from his definition of 'colonial whiteness'. In his vision of the Colonial International, which was to cooperate with or even replace the Third International (1919-1943), ${ }^{18}$ racial and class difference were to be concomitantly tackled. In an almost prophetic gesture, ${ }^{19}$ Sultan-Galiev denounced Eurocentric models of class struggle as a contradictio in terminis when applied in the East: 
We think that the plan to replace one class of European society by the world dictatorship of its adversary - that is, by another class from this same societywill bring no significant change in the situation of the oppressed part of humanity. Even if there would be a change, it would be for the worse, not for the better. ${ }^{20}$

Class differences in the East were, for Sultan-Galiev, inextricably linked to European colonialism and the urban-rural divide it had exacerbated, 'the parasitism and reactionary foundations of the material culture of the metropolis [being] a chief factor of today's global [capitalist] development'. ${ }^{21}$ In this context, anti-colonial, racial and class struggle could not be artificially separated from one another.

It is interesting that further social revolution, which for the majority of his Bolshevik comrades undoubtedly meant the demise of all religions, including Islam, was not for Sultan-Galiev something worth pursuing prior to world revolution. ${ }^{22}$ On closer inspection, one realises that for him this may not have been something worth pursuing at all. ${ }^{23}$ Yet, as the highest-ranking Muslim of the Soviet communist state, ${ }^{24}$ which advocated fervent 'atheisation' of its citizens, Sultan-Galiev could not but accept, if only in principle, this tenet of Bolshevik modernity.

But to understand the very possibility of merging Bolshevik and Muslim modernities in a single revolutionary praxis, one needs to take a step back and consider the larger context in which such interventions were taking place.

\section{On jadìds 'on the left' and Bolsheviks turning 'eastwards'}

The strand of jadīdism into which Mir-Said Sultan-Galiev was (quite literally) born was distinct from that of Gasprinskiı̌'s in the Crimea and still different from the jadì thought in Central Asia. As one of the foremost scholars of this intellectual tradition has averred, jadidism 'was a coherent movement to the extent that it was (or came to be) embedded in a set of self-reproducing institutions (e.g. new-method schools that recruited their own graduates to teach in them). Beyond that, it is difficult to impute any unity to the "movement"'. ${ }^{25}$ Even the way the jadìds commonly called themselves-ziyālilar (intellectuals) and taraqqiparwarlar (progressives) ${ }^{26}$ - attests to a pluralist community of reformers loosely united (but) by a set of common principles. These included their dedication to new methods of production and transmission of knowledge, especially by means of print, translation and pedagogy. Gasprinskilı's attempts to achieve greater unity amongst the jadids through a common literary language did not go down well (especially not amongst the Volga Tatars), neither did the later efforts at creating a number of distinct 'nationalities' out of an irreverently fluid sense of self that seems to have prevailed amongst the late tsarist and early Soviet Muslims. In fact, in many jadìd 
writings in a variety of Turkic and other languages and dialects, 'the distinction between Islam as a faith and Muslims as a community disappears completely'. ${ }^{27}$ Moreover, such Muslim pluralist 'communalism' was not uncommon in many other Third World contexts and was often considered a hallmark of Muslim modernity. ${ }^{28}$

While jadidism was coterminous with the rising awareness amongst Muslims of an increasing political and social importance of the concepts such as 'nation' (millat, millet) or 'homeland' (watan, vatan), ${ }^{29}$ many jadids, along with some other Muslim intellectuals, refused to take such concepts for granted. Instead, they sought to measure them against the perceived borderlines of their imagined community (religious, 'ethnic', linguistic or otherwise) and point to such concepts' numerous shortcomings. Conflating the old Ottoman concept of millet ${ }^{30}$ with the term 'nation' was seen as particularly dangerous, since it could have undermined the greater unity (in diversity) and communality of Muslims. ${ }^{31}$

Besides, jadīdism rose and was in many ways a response to the late-nineteenth and early-twentieth century disintegration of Muslim imperial subjecthood in both Russian and Ottoman empires. The new nation-based concepts of Empire explored both in the early Soviet and Turkish states were met with a mixed response, with some Muslim intelligentsia lamenting the loss of the caliphate ${ }^{32}$ while others saw an opportunity for a reformulation of Muslim identity tout court. The precursors of such debates, including Ismail Gasprinskil̆, while toying with the ideas such as pan-Turkism, always kept in mind the 'big picture', i.e. the Muslim umma as a whole, which needed to be revived from its perceived rigor mortis. ${ }^{33}$ Many members of the later generations of jadids, especially some notable contemporaries of Sultan-Galiev, saw the Russian Revolution of 191734 as an opportunity to do just that, and 'joined it as soon as it was possible'. ${ }^{35}$ No doubt the idea of a Muslim socialist revolution, which the jadids sought to ignite, differed to that of the Bolsheviks. But, importantly, the two factions shared a vested interest in 'revolutionising the East'. For the Bolsheviks, the Third World was increasingly becoming a substitute for their (failed) efforts to revolutionise Europe, while the jadids increasingly saw the Russian Revolution as an opportunity to 'help liberate Muslims of India and the Middle East from the tyranny of the British'36 and the French. It is in this context that the ideas about anti-colonialism and communism, which the jadids sought to link with their Muslim and Turkic 'communalism', began to converge, thus preparing a ground for further cross-fertilisation.

At first, the jadids and other Muslim intellectuals 'on the left' sought to preserve the plurality of their approaches to socialism. Thus, for example, a Muslim Socialist Committee (Müsülman Sosialist Komitesi), which formed in 1917 in Kazan and which Sultan-Galiev soon joined, espoused a great internal diversity of views. ${ }^{37}$ What brought 
them together was the idea of a common revolutionary agency that was Muslim, Third World and socialist/communist in nature. 'In order to prevent the oppression of the toiler of the East', averred Sultan-Galiev in 1918, 'we must unite the Muslim masses in a communist movement that will be our own and autonomous'. ${ }^{38} \mathrm{~A}$ few years later, however, even he began to understand that such a project would require a great deal of manoeuvring within an increasingly hostile Soviet state.

While the Bolsheviks continued to provide concessions for Muslims, including a short-lived return of sharī'a courts and administrative councils, ${ }^{39}$ and made every effort to forge lasting ties with 'the peoples of the East', 40 the 1920s brought a sway of state policies aimed at an ever-increasing central control ${ }^{41}$ that saw Muslim intellectuals, including Sultan-Galiev, wary as to the future of their revolutionary project. With such concerns in mind, Sultan-Galiev and some other Tatar functionaries proposed, in October 1922, that the unfair division of Soviet peoples into 'step-sons and true sons'42 be corrected by allowing the existing autonomous republics and oblasts to enter the Soviet Union directly, that is, to be removed from the RSFSR [Russian Soviet Federative Socialist Republic]'-a proposal Stalin angrily rejected. ${ }^{43}$ By then, however, SultanGaliev's activism moved mostly underground-as if in anticipation of his imminent fall from grace with the Soviet state. ${ }^{44}$

Sultan-Galiev and other Muslim intellectuals 'on the left' become aware of the imperial nature of the rising Stalinist regime very early on:

The theories of the Muslim [...] communists in the 1920s were always tempered by hard realism. [...] Above all, they understood that the Great-Russian imperial tradition was ongoing: that once a territory fell under Russian control it remained for all times a part of the imperium. [...] Theory and practice served the same purpose - to neutralize Great-Russian imperialism at its source, or, if that failed, to defeat it by forming new alliances and new coalitions. ${ }^{45}$

Sultan-Galiev's work in these troubled times followed two major directions: a turn inwards, toward rethinking Muslim subjectivity and praxis, and a dedication to the sophisticated, if dangerous, jadīdist art of concealment (satr).

\section{Double entendre with a tragic ending}

Indicative of his intricate role in mediating between the Soviet and the Muslim spaces in his immediate political milieu are Sultan-Galiev's 1921 articles in Zhizn' natsional'nostei on the supposed 'Methods of Antireligious Propaganda amongst the Muslims'.46 Although he is quick to concede to some utility of such propaganda and, indeed, to declare himself atheist, Sultan-Galiev goes to great pains in these articles to explain to 
his Bolshevik readership that Islam is the youngest and by far the most vigorous of all the great world religions, and one harbouring distinct socialist values at that. 'Sharī'a, or Islamic law', he informs the reader,

governs all aspects of Muslim life on earth [...]. And, of course, among these laws, there are many that are, in essence, positive. Suffice it here to list: compulsory education [...]; compulsory industriousness and work [...]; the parental duty to educate their children until they have reached adulthood; acceptability of civil marriage; denial of private ownership of land, water and forests; repudiation of superstition; prohibition of witchcraft, gambling, luxury, extravagance, gold- and silver-wearing, drinking, bribery and cannibalism [...]; [and] the establishment of an elaborate progressive tax system [...]. Even family and inheritance laws of Islam [were progressive for their time]. For example, the researchers interpreted Muhammad's hadīth on polygamy as effectively delimiting the then widespread polygamous practice. ${ }^{47}$

Sultan-Galiev goes on to praise the Muslim 'clergy', exemplified in the positionalities of the Tatar mullā and the Uzbek 'âlim, who, unlike the Russian Orthodox clergy, generously perform numerous useful positions in the Muslim society, including that of 'priest', teacher, administrator, judge and even doctor, if need be. ${ }^{48}$ The Muslim 'clergy', concludes Sultan-Galiev, consider themselves 'servants' of the people and listen to their constituents' voice, and are, therefore, by far more democratic and enjoy much greater respect and influence than their Russian Orthodox 'counterparts'. 49

The researchers who denounce Sultan-Galiev on the basis of these articles as a militant atheist and therefore firmly on the outside of the Muslim tradition fail, in my view, to understand the true nature of such an intervention in times of most ardent antireligious sentiments actively encouraged by the Soviet state. Far from being yet another piece of anti-religious propaganda, the primary concern of Sultan-Galiev's articles was with painting an overwhelmingly positive picture of Islam and Muslim communities that could, and indeed did, justify their still relatively protected position in an increasingly violent anti-religious state. Declarative atheism with which the author assures his readers of his Bolshevik credentials was likely just that-a faithless expression of faithlessness to secure the necessary, even life-saving, authority of his account. 50

To understand this peculiar double entendre one needs to comprehend the value of satr (concealment) in the jadidist tradition. ${ }^{51}$ The famous Bashkir historian, Turkologist and, in a later stage, leader of the anti-Bolshevik and anti-Soviet revolutionary Basmachi Movement (1916-1934), Ahmet-Zeki Validov (in Bashkir: Äxmätzäki Wälidov; in Turkish: Zeki Velidi Togan; 1890-1970), with whom Sultan- 
Galiev confessed to have maintained 'a complicated relationship',52 once intimated to one Ebubekir the following opinion of Ismail Gasprinskiŭ:

İsmail Bey Gaspıralı had been too servile! [...] It was dangerous for us to encourage the Russians to approach us in the guise of a 'big brother' [...] [and] make love to us in order to betray us. It was better for the future of the colonial peoples to refrain from close mingling, as the English did. 53

Ebubekir replied: 'The ideas of those times were different; moreover, had İsmail Bey said that, his [publications] would never have passed the censorship. In bad times he brought us at least some comfort!'54 Gasprinskiı̌'s talent to evade censors even at the cost of some unseemly alliances has been described by one commentator as 'political quietism'.55 That could be, indeed, another name for political satr, which the jadids employed with great skill and success, ${ }^{56}$ although at times to dismay of their more openly confrontational comrades.

Mir-Said Sultan-Galiev's satr was of an even more sophisticated type. There could be no doubt that he was aware at all times how dangerous a game this was, especially since 1923, the year in which he was arrested for the first time for conspiring - allegedly - to create 'an [anti-Soviet] organisation of the Validov type' and subsequently expelled from the party. ${ }^{57}$ Sultan-Galiev's arrest was ordered after the infamous Soviet secret service, GPU (Gosudarstvennoe politicheskoe upravlenie; State Political Administration), had intercepted his coded letter enjoining an Iranian communist, Tajī Bakhshī, 'to get in touch with Afghani, Indian, Arab and Turkish revolutionaries', supposedly for the purposes of creating the Colonial International.58 The letter warned its reader: 'Only in the unity of revolutionary Eastern countries lies the guarantee of success in the struggle for liberation. And only in that. Never forget this. ${ }^{59}$

It is nothing short of a miracle that Sultan-Galiev survived this episode and even managed to secure his release and regain, at least partly, Stalin's trust. Yet it is precisely his extraordinary talent in keeping up certain outward appearances while concealing from the Soviet regime his less palatable plans and activities that made the final phase of his gradual departure from the Bolshevik ideology almost within reach. If it were not for an additional set of letters intercepted by the ever-watchful GPU, some of which making clear requests to 'make a connection with Zeki Validov',60 leader of the Basmachi Revolt, Sultan-Galiev may have even succeeded in creating a Muslim Third World insurrectionary socialist movement within and beyond the Soviet state. Instead, following a series of further arrests, his death by firing squad was finally authorised by the Stalinist regime and carried out in January 1940. His elimination was accompanied with what was by then the typical Stalinist chistka (purge), in which numerous 
members of the Sultan-Galiev family as well as Tatar Muslim intelligentsia found guilty of sultangalievshchina (Sultan-Galievism) were sent to death.

\section{Epilogue}

Thus ended Sultan-Galiev's experiment with Muslim Marxism, or at least this is how its interbellum phase was finished off. Its legacies, however, have extended far and wide, especially in the times of decolonisation of the 1960s and, even before that, through the revolutionary work of many a non-Soviet student of the Communist University of the Toilers of the East (or KUTV, Kommunisticheskil universitet trudyashchikhsya Vostoka), at which the likes of Tan Malaka, Hồ Chí Minh, Liu Shaoqi, Magomet Mamakaev, Khalid Bakdash, Manabendra Nath Roy and Nazım Hikmet attended Sultan-Galiev's lectures on the 'Colonial East and World Revolution' course. ${ }^{61}$ His work has also been reclaimed by Gamal Abdel Nasser, Ahmed Ben Bella and other political leaders experimenting with various forms of Arab socialism. Both Nasser and Ben Bella are said to have kept SultanGaliev's portraits in their offices, ${ }^{62}$ but the influence of his ideas may not have extended much beyond this symbolic gesture, nowadays easily comparable with the penchant for Che Guevara's portraits, to whom, incidentally, Sultan-Galiev bore a striking physical resemblance.

The peculiarity of Muslim Marxism as espoused by Sultan-Galiev was not only in its methodological idiosyncrasy, whereby the principles such as that of satr had been skilfully employed, in times of trouble, to assist the revolutionary cause. It was also in its early and in many ways avant-garde awareness of religious, cultural and racial connotations of class struggle in colonial and post-colonial contexts. In his unfinished 1924 work titled 'Theses on the Basis of Socio-Political, Economic and Cultural Development of the Turkic Peoples of Asia and Europe', ${ }^{63}$ Sultan-Galiev wrote of the need to reclaim historical materialism as an Eastern intellectual tradition, in a move resembling contemporary calls to end the hegemony of global Northern epistemologies in academia and beyond.64 Muslim insurrectionary subjectivity, upon which SultanGaliev had placed all his hopes and dreams of global socialist freedom, had always been for him an intrinsically complex and multifaceted phenomenon, embodying at once a wide range of ethnic, national and religious practices of belonging, which in turn was conducive of specifically socialist, and indeed revolutionary, Muslim praxis.

Yet, if one is to recast Muslim Marxism of Sultan-Galiev's strand as an expression of radical reform within the Muslim tradition, one ultimately needs to resolve the question of declarative atheism that some have understood to constitute a rapid and irreversible exit from Muslim hieropraxis, tout court. Given the specific context in which it was made, I am reluctant to ascribe to Sultan-Galiev's one-time declaration any 
significance other than that of a strategic move, taking the practice of satr to an extreme level. That all of Marxism does not have to be atheist or agnostic has since been proven particularly in the various Muslim contexts, as it is, indeed, obvious that being Muslim entails an infinitely complex web of practices of belonging. For all these reasons, MirSaid Sultan-Galiev's idea of Muslim Marxism has much to offer to contemporary attempts at reformulation and re-imagination of Muslim post-imperial, religious, political and social selfhood.

\section{Acknowledgements}

Earlier versions of this paper have been presented at Reformers and Intellectual Reformulation in Contemporary Islam, a two-day symposium, 29-30 January 2015, held at SOAS and Queen Mary, University of London; TWAIL Conference: On Praxis and the Intellectual, 21-24 February 2015, held at the American University in Cairo; and Islamic Law and Empire, a two-day miniconference, 1-2 June 2015, held as a part of IGLP: The Conference at Harvard Law School. My thanks are due to the organisers and participants of the exhilarating TWAIL Writing Workshop for this Special Issue of Third World Quarterly for their very helpful comments and suggestions. of course, all errors are mine and mine alone.

\section{Note on author}

Dr Vanja Hamzić is Lecturer in the School of Oriental and African Studies (SOAS), University of London. His legal, anthropological and historical research primarily revolves around human subjectivity formation and insurrectionary vernacular knowledge. He is particularly interested in various Islamic legal traditions and their intersections with Marxist social, political and economic thought. His publications include Control and Sexuality: The Revival of Zina Laws in Muslim Contexts (2010, with Dr Ziba Mir-Hosseini) and Sexual and Gender Diversity in the Muslim World: History, Law and Vernacular Knowledge (2015).

\section{Notes}

${ }^{1}$ Marx, 'Zur Kritik der Hegel'schen Rechts-Philosophie', 72.

${ }^{2}$ Cf. Bennigsen and Lemercier-Quelquejay, Sultan Galiev, le père de la révolution tiers-mondiste, 278.

${ }^{3}$ See generally Rodinson, Marxism and the Muslim World.

${ }^{4}$ As it is undoubtedly known to the readership of this Review, the geo-political designation Third World is as problematic as it is helpful to describe global power-relations. There were many Worlds in the Cold War context that were Third in their relation to the First World powers, some even located within the First and Second Worlds. I use the singular and the plural versions of this designation concomitantly, to underline this plurality. Sultan-Galiev did not use the designation in question, instead opting for the East, which, as we shall see, meant for him something rather similar to the later concept of Third World, including with regards to its 
inherent geo-political plurality. Today's overall preference for the concept of global South is fraught, and perhaps blessed, with similar ambiguities.

${ }^{5}$ See generally Sagadeev, 'Mirsait Sultan-Galiev'.

${ }^{6}$ The most comprehensive collection of Sultan-Galiev's oeuvre is available in Sultan-Galiev, Izbrannye trudy. This publication also contains a comprehensive bibliography of academic works on Sultan-Galiev; ibid., 703-710. A still-relevant critical analysis of sources on SultanGaliev (despite being published in 1986) can be found in Bennigsen and Lemercier-Quelquejay, Sultan Galiev, le père de la révolution tiers-mondiste, 289-300.

${ }^{7}$ See especially the works by Alexandre Bennigsen, Chantal Lemercier-Quelquejay, Hélène Carrère d'Encausse and S. Enders Wimbush listed in the Bibliography for this essay, below. For an interesting work of fiction, see Tengour, Sultan Galièv ou la rupture de stocks.

${ }^{8}$ See, for example, Froese, 'I am an Atheist and a Muslim'.

${ }^{9}$ For two seminal studies on Ismail Gasprinskii in English, see Lazzerini, 'Ismail Bey Gasprinskii and Muslim Modernism in Russia, 1878-1914'; and Lazzerini, 'Ismail Bey Gasprinskii's Perevodchik/Tercüman'.

10 al-Harawī, Fath bāb al-'ināyah bi-sharh al-Niqāyah, 195.

${ }^{11}$ In the Crimea in the 1880s, Gasprinskiu championed a new (phonetic) method (ușūl al-jadīd) of teaching the Arabic alphabet, from which the name of the larger Muslim reformist movement (jadidism) was derived. Jadìd activities primarily concerned Muslim communities in the late Russian Empire and the early Soviet state, but were also present in some other centres of Islamic learning, such as Istanbul and Cairo.

${ }^{12}$ See generally Keller, To Moscow, Not Mecca, 20-25. For a detailed analysis of the jadid educational reforms, albeit with a focus on Central Asia, see Khalid, The Politics of Muslim Cultural Reform, 155-183.

13 Sultan-Galiev, Izbrannye trudy, 27. In Islamic law, the hudūd (lit. 'limits') offences are considered to be the most serious transgressions, for which the penalties are interpreted as prescribed in the Qur'ān itself. Zina is one such offence, relating to adultery or fornication.

${ }^{14}$ A community distinct from the (other) Volga Tatars who seemingly have preserved (more) 'their Finnic ethnic type and speak a special (western) dialect of the Kazan Tatar' language; Bennigsen and Wimbush, Muslims of the Soviet Empire, 233.

${ }^{15}$ Sultan-Galiev, Izbrannye trudy, 476.

16 Ibid., 108.

17 Ibid., 217-218. See also supra n. 4.

${ }^{18}$ Bennigsen and Wimbush, Muslim National Communism in the Soviet Union, 58.

19 That is, long before the Non-Aligned Movement of the 1950s and 1960s would tackle the very same problematic. It is for this reason that Maxime Rodinson famously branded Sultan-Galiev 'a forgotten precursor', while Alexandre Bennigsen and Chantal Lemercier-Quelquejay published a book titled Sultan Galiev, le père de la révolution tiers-mondiste. See Rodinson, Marxism and the Muslim World, 133-141; and Bennigsen and Lemercier-Quelquejay, Sultan Galiev, le père de la révolution tiers-mondiste.

${ }^{20}$ Attributed to Sultan-Galiev by his adversary Tobolev in a propaganda publication, titled Kontrrivolutsiyon Soltangäliefcheleke karshy (Against the Counterrevolutionary SultanGalievism), published in Kazan in 1930; cited in Bennigsen and Wimbush, Muslim National Communism in the Soviet Union, 58. Despite the nature of this publication, there is little doubt that this was, indeed, Sultan-Galiev's view on Eurocentrism. See, for example, Sultan-Galiev, Izbrannye trudy, 215-222.

${ }^{21}$ Sultan-Galiev, Izbrannye trudy, 529.

22 See generally ibid., 525-538.

23 Ibid.

${ }^{24}$ Mir-Said Sultan-Galiev 'took part in the First All-Russian Muslim Congress of May 1917 in Kazan and in July 1917 became one of the leading members of the Muslim Socialist Committee of Kazan. In November 1917 he entered the [Russian Communist Party (Bolshevik)] and, because of his exceptional gifts for organization, rapidly became the highest-ranking Muslim in 
the CP hierarchy - member of the Central Muslim Commissariat, chairman of the Muslim Military Collegium, member of the Little Collegium of the Narkomnats [People's Commissariat of Nationalities], editor of Zhizn' natsional'nostei, the official organ of the Narkomnats, and member of the Central Executive Committee of the Tatar Republic'; Bennigsen and Wimbush, Muslim National Communism in the Soviet Union, 207-208. For an alternative short account of Sultan-Galiev's many functions within the Soviet state, see Davletshin, Sovetskil Tatarstan, n. 19, 133-134.

${ }^{25}$ Khalid, The Politics of Muslim Cultural Reform, 8-9.

26 Ibid., 93.

${ }^{27}$ Ibid., 193. Even the language in which such writings appeared was often called 'Muslim language' (musulmān tili, müsülman tili, musul'manskĭ iazyk).

${ }^{28}$ Muslim modernity (or Islamic modernism) is often described as an idée recue, based on both traumatic and 'productive' Muslim experiences with European Enlightenment, modernity and colonialism. The phenomenon is, however, much larger in scope, and can arguably be traced back to various historical Muslim polities long before the late nineteenth century, i.e. before the time of the well-established Muslim modernist reformers, such as Muhammad 'Abduh (18491905) and Jamāl al-Dīn al-Afghānī (1838-1897). As such, Muslim modernity can be compared to other historical examples of 'early modern' phenomena around the world; see, for example, Goldstone, 'The Problem of the "Early Modern" World', 249-284. With his ideas about progress and reform, Ismail Gasprinskil can certainly be counted amongst the Muslim modernists of his time.

${ }^{29}$ See especially Khalid, The Politics of Muslim Cultural Reform, 184-187; and Critchlow, 'Vatan and the Concept of "Homeland" in the Muslim Soviet Republics', 481-488.

30 The Ottoman usage of the word millet prior to the Tanzimât (1839-1876) primarily related to the (legal) concept of a separate confessional community, self-governed via its own system of personal laws. The Tanzimât brought a new usage of the term, more akin to the concept of 'nation', although a number of communities it pertained to were still primarily confessional. In modern Turkish, millet translates as 'nation'.

31 Thus, for example, in Ottoman Turkish, a separate word for 'nation' - milliyet - was used to distinguish it from the more open-ended concept of millet. See Meyer, Turks Across Empires, 120-121.

${ }^{32}$ Centuries-long Ottoman sultans' claim to caliphal authority ended in 1924, when Mustafa Kemal Atatürk abolished the office of the caliph, much to dismay across the Sunnī Muslim world. The caliph (in Arabic: khalifa) is traditionally considered to be the Prophet Muhammad's deputy, or successor, on Earth, and thereby a rightful ruler over the Muslim umma.

${ }^{33}$ Gasprinskil claimed that, after the third century AH, 'the Muslim world was reduced to (a condition of) rigor mortis'; a condition he thought he could change with his 'reason-centred' educational and social policies; Lazzerini, 'Ismail Bey Gasprinskii and Muslim Modernism in Russia, 1878-1914', 157. However, Gasprinskil did not think that such change could be brought by means of socialism, which he rejected as an illusion; ibid., 163.

${ }^{34}$ That is, both the February Revolution in March 1917 and the October Revolution in November the same year.

${ }^{35}$ Khalid, The Politics of Muslim Cultural Reform, 288.

36 Khalid, Islam after Communism, 56.

${ }^{37}$ Bennigsen and Quelquejay, Les mouvements nationaux chez les musulmans de Russie, 70-71.

${ }^{38}$ Sultan-Galiev, cited in Bennigsen and Wimbush, Muslim National Communism in the Soviet Union, 46. In March 1918, Sultan-Galiev founded the Muslim Communist-Socialist Party, which maintained its independence from the Russian Communist Party for some time. See Carrère d'Encausse, The Great Challenge, 141.

${ }^{39}$ For an example from Turkestan, see Khalid, Islam after Communism, 61.

40 Of which the Congress of the Peoples of the East in Baku in September 1920, organised by the Communist International, was perhaps the most symbolic, if eventually unsuccessful, project. The capital of Azerbaijan was, in that period, hailed as a 'Mecca of the anti-imperial struggle' for 
the sheer number of Muslim revolutionaries present there. See Dumont, 'Bakou, carrefour révolutionnaire, 1919-1920', 414.

${ }^{41}$ One such policy was razmezhevanie (delimitation) that led, inter alia, to dissolution, in 1924, of the Turkestan Soviet Socialist Republic into several smaller Soviet republics and oblasts. The dissolution of Turkestan was seen by many Soviet Muslims as an attempt of the early Stalinist state to exert greater control over their affairs.

${ }^{42}$ Sultan-Galiev, Izbrannye trudy, 409.

43 Martin, The Affirmative Action Empire, 397.

${ }^{44}$ Unfortunately for Sultan-Galiev, his 'going underground' did not go unnoticed. Several months before denouncing Sultan-Galiev in a speech to the delegates of the Fourth Conference of the Central Committee of the Communist Party of the USSR, on 10 June 1923, Stalin himself apparently warned Sultan-Galiev that he was 'playing a dangerous game'; see Baker, 'Did He Really Do It?', 599. For the full transcript of Stalin's speech, in which he accused Sultan-Galiev of both pan-Turkism and pan-Islamism, see Stalin, "Rights and "Lefts" in the National Republics and Regions', 308-319.

45 Bennigsen and Wimbush, Muslim National Communism in the Soviet Union, 51.

${ }^{46}$ Sultan-Galiev, Izbrannye trudy, 363-374.

47 Ibid., 363-364.

48 Ibid., 364.

49 Ibid.

${ }^{50}$ Alternatively, the possibility of a faithless Muslim may have signalled the forging of a radical take on Muslim subjectivity, which, while persistently denounced in the mainstream Muslim traditions, would not be dissimilar to explorations of agnosticism and atheism in other Abrahamic traditions, most notably in liberal Jewish theology. See, for example, Kaplan, The Meaning of God in Modern Jewish Religion.

${ }^{51}$ In the larger Islamic tradition, the jadids' and Ottoman art of satr (concealment) could be compared to the Sunnī legal and philosophical device of idtirīar (compulsion) and the Shīì concept of taqiyya (dissimulation) - both of which render concealment of one's true religious beliefs and hieropraxis permissible in times of extreme danger and duress.

52 Sultan-Galiev, Izbrannye trudy, 511-512.

53 Velidi Togan, Bugünkü Türkili (Türkistan) ve Yakın Tarihi, 556.

54 Ibid.

55 Kuttner, 'Russian Jadìdism and the Islamic World', 384.

56 The employment of satr is certainly not the only example of the jadids' giving an old (in this case: Ottoman) social tool a new use. Writing about the early-twentieth-century Central Asian jadid discourse, Adeeb Khalid describes how the jadids "had appropriated the literary device of ibrat - taking admonition from noteworthy example - which had deep roots in Islamic tradition but was now given a new form'; Khalid, 'Representations of Russia in Central Asian Jadid Discourse', 197.

${ }^{57}$ Rossiiskaya kommunisticheskaya partiya (bol'shevik). Tainy national'noi politiki TsK RKP, 16; cited in Baker, 'Did He Really Do It?', 599.

${ }^{58}$ Sultanbekov and Sharafutdinov, Neizvestnyi Sultan-Galiev, 37-38; cited in Baker, 'Did He Really Do It?', 601.

59 Ibid.

60 Sultan-Galiev, Izbrannye trudy, 471.

61 Tagirov and Sultanbekov, 'Velikil providets', 7.

62 Ibid. For an overview of Arab communist ideas and movements in the twentieth century and their relations with Sultan-Galiev's oeuvre, see generally Ismael, The Communist Movement in the Arab World.

${ }^{63}$ Sultan-Galiev, Izbrannye trudy, 525-538.

${ }^{64} \mathrm{See}$, for example, de Sousa Santos, Another Production is Possible; Comaroff and Comaroff, Theory from the South; and Chakrabarty, Provincializing Europe. 


\section{Bibliography}

Akademiiu nauk Tatarstana. Islam v istorii i kul'ture tatarskogo naroda. Kazan: Shkola, 2000.

al-Harawī, 'Ālī ibn Sulțān al-Qārī'. Fatḥ bāb al-'ināyah bi-sharḥ al-Niqāyah. Vol. 3. Edited by M.N. Tamīm and H.N. Tamìm. Beirut: Dār al-Mu'arrikh al-'Arabī, 1997 [c.1601].

Baker, Mark R. 'Did He Really Do It?: Mirsaid Sultan-Galiev, Party Disloyalty, and the 1923 Affair.' Europe-Asia Studies 66, no. 4 (2014): 590-612.

Bennigsen, Alexandre, and Chantal Lemercier-Quelquejay. La presse et le mouvement national chez les musulmans de Russie avant 1920. Paris: Mouton, 1964.

Bennigsen, Alexandre, and Chantal Lemercier-Quelquejay. Le soufi et le commissaire: Les confréries musulmanes en URSS. Paris: Éditions du Seuil, 1986.

Bennigsen, Alexandre, and Chantal Lemercier-Quelquejay. Sultan Galiev, le père de la révolution tiers-mondiste. Paris: Fayard, 1986.

Bennigsen, Alexandre, and Chantal Quelquejay. Les mouvements nationaux chez les musulmans de Russie: Le 'sultangalievisme' au Tatarstan. Paris: Mouton, 1960.

Bennigsen, Alexandre, and S. Enders Wimbush. Muslim National Communism in the Soviet Union: A Revolutionary Strategy for the Colonial World. Chicago: University of Chicago Press, 1979.

Bennigsen, Alexandre, and S. Enders Wimbush. Muslims of the Soviet Empire: A Guide. Bloomington, IN: Indiana University Press, 1986.

Bennigsen, Alexandre, Paul B. Henze, George K. Tanham and S. Enders Wimbush. Soviet Strategy and Islam. London: Macmillan, 1989.

Brower, Daniel R., and Edward J. Lazzerini, eds. Russia's Orient: Imperial Borderlines and Peoples, 1700-1917. Bloomington, IN: Indiana University Press, 1997.

Carrère d'Encausse, Hélène. Islam and the Russian Empire: Reform and Revolution in Central Asia. Translated by Quintin Hoare. Berkeley, CA: University of California Press, 1988 [1966].

Carrère d'Encausse, Hélène. The Great Challenge: Nationalities and the Bolshevik State, 19171930. Translated by Nancy Festinger. New York: Holmes \& Meier, 1992 [1987].

Chakrabarty, Dipesh. Provincializing Europe: Postcolonial Thought and Historical Difference. Princeton, NJ: Princeton University Press, 2000.

Comaroff, Jean, and John Comaroff. Theory from the South: Or, How Euro-America is Evolving toward Africa. Boulder, CO: Paradigm, 2012.

Crews, Robert D. For Prophet and Tsar: Islam and Empire in Russia and Central Asia. Cambridge, MA: Harvard University Press, 2006.

Critchlow, James. 'Vatan and the Concept of "Homeland” in the Muslim Soviet Republics.' In Passé turco-tatar, présent soviétique: Études offertes à Alexandre Bennigsen, edited by Ch. Lemercier-Quelquejay, G. Veinsten and S.E. Wimbush, 481-488. Leuven: Éditions Peeters, 1986.

Davletshin, Tamurbek. Sovetskĭ Tatarstan: Teoriia i praktika Leninskǒ politiki. London: Our World, 1974.

de Sousa Santos, Boaventura. Another Production is Possible: Beyond Northern Epistemologies. Vol. 3. London: Verso, 2006.

Dumont, Paul. 'Bakou, carrefour révolutionnaire, 1919-1920.' In Passé turco-tatar, présent soviétique: Études offertes à Alexandre Bennigsen, edited by Ch. Lemercier-Quelquejay, G. Veinsten and S.E. Wimbush, 413-433. Leuven: Éditions Peeters, 1986.

Froese, Paul. 'I am an Atheist and a Muslim": Islam, Communism, and Ideological Competition.' Journal of Church and State 47, no. 3 (2005): 473-501.

Goldstone, Jack A. 'The Problem of the "Early Modern” World.' Journal of the Economic and Social History of the Orient 41, no. 3 (1998): 249-284.

Hostler, Charles Warren. Turkism and the Soviets: The Turks of the World and their Political Objectives. London: George Allen \& Unwin, 1957.

Ismael, Tareq Y. The Communist Movement in the Arab World. London: Routledge, 2005. 
Kanlidere, Ahmet. Reform within Islam: The Tajdid and Jadid Movement among the Kazan Tatars, 1809-1917. Istanbul: EREN Yayıncıllk, 1997.

Kaplan, Mordecai M. The Meaning of God in Modern Jewish Religion. Detroit, MI: Wayne State University Press, 1995 [1947].

Keller, Shoshana. To Moscow, Not Mecca: The Soviet Campaign against Islam in Central Asia, 1917-1941. Westport, CT: Praeger, 2001.

Khalid, Adeeb. 'Representations of Russia in Central Asian Jadid Discourse.' In Russia's Orient: Imperial Borderlines and Peoples, 1700-1917, edited by Daniel R. Brower and Edward J. Lazzerini, 188-202. Bloomington, IN: Indiana University Press, 1997.

Khalid, Adeeb. Islam after Communism: Religion and Politics in Central Asia. Berkeley, CA: University of California Press, 2007.

Khalid, Adeeb. The Politics of Muslim Cultural Reform: Jadidism in Central Asia. Berkeley, CA: University of California Press, 1998.

Kuttner, Thomas. 'Russian Jadìdism and the Islamic World: Ismail Gasprinskii in Cairo, 1908.' Cahiers du Monde russe et soviétique 16, no. 3-4 (1975): 383-424.

Landa, R.G. 'Mirsaid Sultan-Galiev.' Voprosy istorii 8 (1999): 53-70.

Lazzerini, Edward J. 'Ismail Bey Gasprinskii's Perevodchik/Tercüman: A Clarion of Modernism.' In Central Asian Monuments, edited by Hasan B. Paksoy, 143-156. Istanbul: Isis Press, 1992.

Lazzerini, Edward James. 'Ismail Bey Gasprinskii and Muslim Modernism in Russia, 1878-1914.' $\mathrm{PhD}$ thesis, University of Washington, 1973.

Lemercier-Quelquejay, Ch., G. Veinsten and S.E. Wimbush, eds. Passé turco-tatar, présent soviétique: Études offertes à Alexandre Bennigsen. Leuven: Éditions Peeters, 1986.

Martin, Terry. The Affirmative Action Empire: Nations and Nationalism in the Soviet Union, 19231939. Ithaca, NY: Cornell University Press, 2001.

Marx, Karl. 'Zur Kritik der Hegel'schen Rechts-Philosophie.' Deutsch-Französischen Jahrbüchern 1, no. 1 (1844): 71-85.

Meyer, James H. Turks Across Empires: Marketing Muslim Identity in the Russian-Ottoman Borderlands, 1856-1914. Oxford: Oxford University Press, 2014.

Mukhametshin, Rafik. Islam v tatarskor̆ obshchestvennoI mysli nachala XX veka. Kazan: Iman, 2000.

Rodinson, Maxime. Marxism and the Muslim World. London: Zed Books, 2015 [1972].

Rossiiskaya kommunisticheskaya partiya (bol'shevik). Tainy national'noi politiki TsK RKP: Stenograficheskil otchet sekretnogo IV soveshchaniya TsK RKP, 1923. Moscow: INSAN, 1992.

Sadur, Valiahmet. Tiurki, Tatary, musul'mane: Stat'i, ocherki, ésse. Moscow: Mardzhani, 2012.

Sagadeev, Artur Vladimirovich. 'Mirsait Sultan-Galiev: Revoliutsioner i myslitel'.' Nasha rodina i sovremenny mir 20, no. 3 (1998): 38-52.

Stalin, J.V. 'Rights and "Lefts" in the National Republics and Regions: Speech on the First Item of the Conference Agenda: "The Sultan-Galiyev Case", June 10.' In Works. Vol. 5, 308-319. Moscow: Foreign Languages Publishing House, 1953.

Sultan-Galiev, Mir-Said K. Izbrannye trudy. Edited by I.G. Gizzatullin and D.R. Sharafutdinov. Kazan: Izdatel'stvo Gasyr, 1998.

Sultanbekov, B.F., and D.R. Sharafutdinov, eds. Neizvestnyi Sultan-Galiev: Rassekrechennye dokumenty i materialy. Kazan: Tatarskoe knyzhnoe izdatel'stvo, 2002.

Tagirov, Indus, and Bulat Sultanbekov, 'Velikiǐ providets'. In Izabrannye trudy, by Mir-Said Sultan-Galiev, edited by I.G. Gizzatullin and D.R. Sharafutdinov. Kazan: Izdatel'stvo Gasyr, 1998.

Tengour, Habib. Sultan Galièv ou la rupture de stocks: Cahiers, 1972/1977. Paris: Sindbad, 1985.

Vahidov, H. Prosvetitel'skaia ideologiia $v$ Turkestane. Tashkent: Uzbekistan, 1979.

Velidi Togan, Zeki. Bugünkü Türkili (Türkistan) ve Yakın Tarihi. Istanbul: Arkadaş / İbrahim Horoz ve Güven Basımevleri, 1942. 
